\title{
Characteristics of biofilms and iron corrosion scales with ground and surface waters in drinking water distribution systems
}

\author{
Xiaoxiao $\mathrm{Li}^{\mathrm{a}}$, Haibo Wang ${ }^{\mathrm{a}}$, Chun $\mathrm{Hu}^{\mathrm{a}, *}$, Min Yang ${ }^{\mathrm{a}}$, Hongying $\mathrm{Hu}^{\mathrm{b}}$, Junfeng $\mathrm{Niu}^{\mathrm{c}}$ \\ ${ }^{a}$ Key Laboratory of Drinking Water Science and Technology, Research Centre for Eco-Environmental Sciences, Chinese Academy of Sciences, Beijing 100085, China \\ ${ }^{\mathrm{b}}$ School of Environment, Tsinghua University, Beijing 100084, China \\ ' School of Environment, Beijing Normal University, Beijing 100875, China
}

\section{A R T I C L E I N F O}

\section{Article history:}

Received 2 May 2014

Accepted 22 October 2014

Available online 28 October 2014

\section{Keywords:}

A. Iron

B. XRD

B. SEM

C. Microbiological corrosion

\begin{abstract}
A B S T R A C T
The composition of biofilm bacterial communities and iron corrosion scales were studied in two drinking water distribution systems transporting groundwater (DWDS-GW) and surface water (DWDS-SW). Loose corrosion products were formed containing $\alpha-\mathrm{FeOOH}$ in DWDS-GW, while dense crystallized particles were formed in DWDS-SW, including $\alpha-\mathrm{FeOOH}, \mathrm{Fe}_{3} \mathrm{O}_{4}$ and $\mathrm{CaCO}_{3}$. The biofilms in the two systems had the same bacterial diversity, denitrifying functional genes and 16S rRNA gene copies, but the bacterial communities were very different. It was found that nitrate-reducing bacteria in biofilms that are associated with iron cycling played a large role in the formation of $\mathrm{Fe}_{3} \mathrm{O}_{4}$ and corrosion layers.
\end{abstract}

(c) 2014 Elsevier Ltd. All rights reserved.

\section{Introduction}

Cast iron pipes have been used in drinking water distribution systems (DWDSs) for over 500 years [1]. Corrosion of cast iron pipes is the most common distribution system problem [2-4], and it can cause three distinct but related problems: pipe mass loss, decreasing water capacity, and production of red water at the tap. Corrosion scales in iron pipes interact with finished water with resulting adverse effects on distribution water quality, possibly leading to release of undesirable substances.

In recent years, several serious red water cases have occurred due to switching of source water, such as in Southern California, Tucson, Arizona and Tampa, Florida in the United States [5-7]. In October, 2008, red water appeared in some areas in a city in Northern China soon after $80 \%$ of the local source water was replaced with source water from a neighboring province. It was noticed that the areas suffering from red water were historically supplied with local groundwater, but the areas without red water were historically supplied with local surface waters [8]. The Tucson, Arizona and Tampa, Florida red water cases were also caused by source water switches from groundwater to surface water. These phenomena indicated that the structure and morphology of corrosion scales played important roles in changes of distribution water quality from the interaction of corrosion scales with finished water. It was reported that thick corrosion scales or densely

\footnotetext{
* Corresponding author. Tel.: +86 10 62849628; fax: +86 1062923541 .

E-mail address: huchun@rcees.ac.cn (C. Hu).
}

distributed corrosion tubercles were mostly found in pipes transporting surface water, but thin corrosion scales and hollow tubercles were mostly discovered in pipes transporting groundwater [8]. Unstable and less protective corrosion scale is one of the main factors causing red water when the quality of water entering a distribution system changes significantly. Therefore, previous studies of iron pipe corrosion have focused on pipe degradation, corrosion scale formation, and iron release. A large number of factors were examined for their influence on iron pipe corrosion parameters, including water quality and composition, flow conditions, biological activity, and corrosion inhibitors [9-11]. In particular, some contradictory results have appeared on the effects of chloride and sulfate on iron corrosion $[1,12,13]$, so the LarsonSkold Index does not provide an effective means of controlling iron corrosion, and biofilms may be used as an alternative method to combat corrosion [14].

Microbes perform oxidation and reduction reactions with iron to greatly affect the stability of minerals in the environment and are thought to play an important role in iron transformation $[15,16]$. Microbiologically influenced corrosion (MIC) affects diverse processes in DWDSs. Some theories about possible mechanisms of MIC exist, with the process depending on both the type of microorganisms involved and the environmental conditions experienced. The existing literatures on MIC are somewhat complex and confusing because bacterial activity at metal surfaces has been shown to both increase and in some cases reduce corrosion rates $[17,18]$. It is estimated that approximately $20 \%$ of annual damage due to corrosion in metals results from microbial activities, of which a 
significant part is due to aerobic corrosion influenced by iron-oxidizing bacteria (IOB) [19]. In addition, anaerobes such as sulfatereducing (SRB) and iron-reducing bacteria (IRB) were reported to promote corrosion [20,21], while IRB exhibited a protective effect in other studies [22]. Recently, Xu et al. [23] found that a nitrate reducer was more corrosive than typical SRB by pitting data under strict anaerobic conditions. On the other hand, the nitrate-dependent $\mathrm{Fe}(\mathrm{II})$ oxidation from nitrate-reducing bacteria (NRB) metabolism has the potential to contribute to a dynamic iron redox cycle in freshwater sediments [16], which has been proven inhibiting iron corrosion [24]. Additionally, more and more studies have begun to show protective effects against corrosion by some bacterial biofilms on metal. Biofilms comprising iron-respiring bacteria, such as Bacillus infernos, Desulfovibrio profundus, and Geothrix fermentans, may reduce rather than accelerate the corrosion rate of steel [14]. Recent progress in corrosion inhibition using beneficial bacterial biofilms (BBB) has been reviewed [25]. Biofilm communities on corrosion scales are heterogeneous in DWDSs, so their effects on corrosion predominantly depend on the environmental characteristics of the metal/biofilm/medium interface.

In this present study, groundwater (GW) and surface water (SW) were selected to investigate the effects of water-bacterial community composition of biofilms and corrosion of cast iron pipes in DWDSs. Corrosion behavior and corrosion scales were characterized by X-ray powder diffraction (XRD), scanning electron microscopy (SEM) and Brunauer-Emmett-Teller (BET) analysis. Quantitative real-time PCR ( $\mathrm{PPCR}$ ) was used to monitor changes in the microbial abundances of biofilms inside corrosion scales according to specific groups: total bacteria based on the 16S rRNA gene and denitrifiers based on the functional genes nosZ, nirK and nirS. Most probable number enumerations of NRB, IRB and nitrate-dependent Fe(II)-oxidizing microorganisms were detected under different conditions for different corrosion scale biofilms. Pyrosequencing was used to monitor changes in diversity in the microbial community of biofilms, including corrosion-related bacteria. The relationship between corrosion and biofilms is discussed.

\section{Materials and methods}

\subsection{Source water}

This study focused on two principal water sources, groundwater (GW) and surface water (SW), in Northern China. The GW source is untreated groundwater prior to contact tank chlorination. The tested SW was treated by chemical precipitation and flocculation, settling, sand filtration, and biologically activated carbon filtration (prior to entering the chlorine contact tanks) in a drinking water treatment plant.

\subsection{Pilot pipe distribution systems}

Two pilot distribution systems were assembled with new cast iron pipe materials to transport GW and SW. The length of each line was approximately $50 \mathrm{~cm}$. Pipe diameters were $10 \mathrm{~cm}$. The elemental compositions (wt.\%) of the cast iron pipe were C $3.21 \%$, O $1.63 \%$, Al 1.1\%, Si 1.85\%, and Fe $92.21 \%$. The pilot systems were operated with a two-day hydraulic retention time (HRT) to reflect dead zones or worst-case conditions in an actual distribution system [7], in order to study the formation of corrosion scales and changes in biofilms. Chlorine was dosed from a stock solution of sodium hypochlorite $(\mathrm{NaClO})$. The initial chlorine concentration in influents was approximately $10 \mathrm{mg} \mathrm{L}^{-1}$ in the two DWDSs, and the average chlorine concentration in effluents of GW and SW DWDSs was $0.27 \mathrm{mg} \mathrm{L}^{-1}$ and $0.13 \mathrm{mg} \mathrm{L}^{-1}$, respectively.

\subsection{Weight loss}

To determine the corrosion rate in DWDSs, cast iron coupons, $80 \times 15 \times 5 \mathrm{~mm}$, were immersed in covered $250 \mathrm{~mL}$ glass bottles filled with each of GW and SW containing chlorine disinfection, respectively. The bottles were kept in dark and triplicates were measured monthly. The elemental compositions (wt.\%) of the iron coupons were C $19.08 \%$, O $6.09 \%$, Si $2.06 \%$, Ca $0.58 \%$, P $0.65 \%$, S $1.60 \%$, Fe $65 \%$, Cu $1.98 \%$, Mn $0.92 \%$, Zn $2.04 \%$. The water was displaced with fresh water at $2 \mathrm{~d}$ intervals same as the tested pilot systems with a two-day hydraulic retention time. The weight loss method was utilized to determine the corrosion rate [24].

\subsection{Physicochemical analysis}

Water quality parameters, such as $\mathrm{pH}$, alkalinity and chlorine concentration, were analyzed according to standard methods [26]. Chloride $\left(\mathrm{Cl}^{-}\right)$, sulfate $\left(\mathrm{SO}_{4}^{2-}\right)$ and nitrate $\left(\mathrm{NO}_{3}^{-}\right)$were analyzed by ion chromatography (DIONEX ICS-2000). Dissolved oxygen (DO) was monitored with an Orion 4 Star meter (Thermo, USA). The Larson-Skold Index (LI) was calculated using the concentration of chlorides, sulfates and bicarbonates [27]:

$\mathrm{LI}=\frac{\left[\mathrm{Cl}^{-}\right]+2\left[\mathrm{SO}_{4}^{2-}\right]}{\left[\mathrm{HCO}_{3}^{-}\right]}$.

The corrosion scales were measured by an X-ray powder diffractometer (X'Pert PRO MPD, PANalytical, Almelo, The Netherlands) and photographed using scanning electron microscopy (SEM) (S-3000N, Hitachi, Japan). Nitrogen adsorption/desorption experiments were carried out on various samples using a Micromeritics ASAP 2020 analyser (Micromeritics ASAP 2020, USA).

\subsection{Sampling and extraction of total DNA from water and biofilms}

For bulk water samples, bacteria from $3 \mathrm{~L}$ of each water sample were harvested by membrane filtration with $0.22 \mu \mathrm{m}$ Millipore GTTP filters and then transferred to sterile tubes for isolation [28]. For corrosion scales with biofilms, samples were collected with a sterile metal spatula scraping approximately $3 \mathrm{~cm}^{2}$ surface area from 6 different locations on each pipe [29]. Then, the samples from the same pipe were mixed and lyophilized for further characterization.

DNA was extracted in triplicate samples with the Fast DNA ${ }^{\circledR}$ SPIN Kit for soil (MP Biomedicals, Solon, OH, USA) according to the manufacturer's instructions [30]. DNA quality was checked on an agarose gel, and concentrations were measured with a NanoDrop (ND-1000, NanoDrop, USA). All DNA samples were stored at $-80^{\circ} \mathrm{C}$ for future use.

\subsection{Quantitative PCR assay}

To quantify all bacteria and denitrifiers in water and biofilm samples, quantitative PCR (qPCR) targeting 16S rRNA, nirK, nirs and nos $Z$ genes was performed. For all bacteria, primer pairs $1369 \mathrm{~F}$ and $1492 \mathrm{R}$ were combined with probe TM1389F [31]; for denitrifiers, nirK 876 and nirK 1040, R3cd and cd3aF, and nosZ-F and 1622R were used (Table 1) [32-34]. qPCR experiments were carried out with the Applied Biosystems 7300 qPCR system using premix Ex Taq ${ }^{\mathrm{TM}}$ or SYBR $^{\circledR}$ premix Ex Taq ${ }^{\mathrm{TM}}$ (TaKaRa) in a $25 \mu \mathrm{L}$ reaction volume. The annealing temperatures used were $60^{\circ} \mathrm{C}$ for universal primer pairs, $55^{\circ} \mathrm{C}$ for nirK $876 /$ nirK $1040,53^{\circ} \mathrm{C}$ for $\mathrm{R} 3 \mathrm{~cd} / \mathrm{cd} 3 \mathrm{aF}$ and $58{ }^{\circ} \mathrm{C}$ for nosZ-F/1622R, which were determined by gradient PCR to be the most suitable for the present samples. 
Table 1

Primer paris used for qPCR analysis.

\begin{tabular}{lll}
\hline Designation & Sequence $\left(5^{\prime}-3^{\prime}\right)$ & Target \\
\hline 1369F & CGGTGAATACGTTCYCGG & All bacteria 16S rRNA \\
1492R & TACGGYTACCTTGTTACGACTT & \\
Probe TM1389F & TACGGYTACCTTGTTACGACTT & \\
nirK 876 & ATYGGCGGVCAYGGCGA & Denitrifying bacteria nirK \\
nirK 1040 & GCCTCGATCAGRTTRTGGTT & \\
cd3aF & AACGYSAAGGARACSGG & Denitrifying bacteria nirS \\
R3cd & GASTTCGGRTGSGTCTTSAYGAA & \\
nosZ-F & CGYTGTTCMTCGACAGCCAG & Denitrifying bacteria nosZ \\
$1622 \mathrm{R}$ & CGSACCTTSTTGCCSTYGCG & \\
\hline
\end{tabular}

\subsection{Pyrosequencing analysis}

DNA was amplified with bacterium-specific forward primer 341F (5'-Fusion A-Barcode-CA linker-CCTACGGGAGGCAGCAG-3') and reverse primer 1073R (5'-Fusion B-TC linker-ACGAGCTGACGACARCCATG-3') [30]. The PCR products of three independent reactions were pooled together, purified with the AxyPrep DNA Gel Extraction Kit (Axygen, USA), and quantified using a TBS-380 Fluorometer (Turner Biosystems, USA). Before pyrosequencing, PCR products from different samples were normalized to equimolar amounts in the final mixture, which was used to construct PCR amplicon libraries. The pyrosequencing was carried out on a Roche massively parallel 454 GS-FLX Titanium sequencer (Roche 454 Life Sciences, Branford, CT, USA) according to standard protocols. Pyrosequencing flowgrams were converted to sequence reads using MOTHUR software (http://www.mothur.org/) and then analyzed using the UCHIME (http://www.drive5.com/uchime) standard pipeline. Sequence reads were initially filtered and denoised to remove low quality or ambiguous reads. High quality sequences ( $>200$ bp in length, quality score $>25$, exact match to barcode and primer, and containing no ambiguous characters) remained with an average length of $436 \mathrm{bp}$. The total bacterial communities were analyzed for the number of operational taxonomic units (OTUs) and species richness using the Mothur program. The numbers of OTUs were estimated at 97\% 16S rRNA gene sequence similarity. Taxonomic positions of representative sequences were assigned using the SILVA database (http://www.arb-silva.de/).

\subsection{Most probable number (MPN) enumerations}

In the all MPN experiments, for corrosion scales with biofilms, samples were scraped with a sterile metal spatula on the surface of each pipe. Upon return to laboratory, corrosion scales were homogenized and placed in an $\mathrm{N}_{2}$ atmosphere at room temperature. The abundance of culturable acetate-oxidizing NRB, acetateoxidizing IRB and nitrate-dependent $\mathrm{Fe}(\mathrm{II})$-oxidizing microorganisms of biofilms inside corrosion scales were estimated using a three-tube MPN technique [16]. Triplicate pressure tubes containing sterile, anaerobic $\left(\mathrm{N}_{2}\right)$ AGW medium (10 mM PIPES, $2 \mathrm{mM}$ $\mathrm{NaHCO}_{3}, 5 \mathrm{mM} \mathrm{NH} \mathrm{H}_{4} \mathrm{Cl}, 0.5 \mathrm{mM} \mathrm{KH_{2 }} \mathrm{PO}_{4}, \mathrm{pH} 6.8$ ) were inoculated with serially diluted homogenized corrosion scales. For enumeration of acetate-oxidizing NRB, tubes were amended with $5 \mathrm{mM}$ $\mathrm{NaNO}_{3}$ and $10 \mathrm{mM} \mathrm{Na}$-acetate. Acetate-oxidizing, IRB were enumerated in medium amended with $10 \mathrm{mM}$ synthetic hydrous ferric oxide, $10 \mathrm{mM}$ Na-acetate and $2 \mathrm{mM} \mathrm{FeCl}_{2}$ (as a reducing agent). The medium for enumeration of nitrate-dependent $\mathrm{Fe}$ (II)-oxidizing bacteria was amended with $0.5 \mathrm{mM} \mathrm{Na}$-acetate, $5 \mathrm{mM} \mathrm{NO}_{3}^{-}$and $10 \mathrm{mM} \mathrm{FeCl}_{2}$. Pressure tubes were incubated statically in the dark at $30{ }^{\circ} \mathrm{C}$ for 10 weeks. Positive results for acetate-oxidizing nitrate reducers were determined checking for depletion of $\mathrm{NO}_{3}^{-}$(to $<1 \mathrm{mM}$ ). Visual assessment of medium blackening and formation of reddish-brown precipitates was used to identify positive results for $\mathrm{Fe}(\mathrm{III})$ reducers and nitrate-dependent Fe(II) oxidizers, respectively. Hydrous ferric oxide was synthesized according to the described method [35].

\subsection{Statistical analysis}

Student's paired $t$-tests were performed on experimental data using SPSS software (version 16.0), and $p<0.05$ was considered statistically significant.

\section{Results}

\subsection{Water quality of water sources and effluents}

Significant differences between the water quality of groundwater (GW) and surface water (SW) are listed in Table 2. In GW, the concentration of nitrate- $\mathrm{N}$ was $5.04-7.89 \mathrm{mg} \mathrm{L}^{-1}$, LI was $0.22-$ 0.31 ; and these values were $0.87-2.17 \mathrm{mg} \mathrm{L}^{-1}, 0.60-1.05$ in SW, respectively. In the effluents from DWDSs, DO decreased $(p<0.05)$ to approximately $1 \mathrm{mg} \mathrm{L}^{-1}$. Alkalinity in GW and SW DWDSs decreased to $118 \mathrm{mg} \mathrm{L}^{-1} \quad(p<0.05)$ and $89 \mathrm{mg} \mathrm{L}^{-1}$ $(p<0.05)$, respectively; the $\mathrm{pH}$ and $\mathrm{SO}_{4}^{2-}$ did not change significantly, and together with the change in chloride concentration, resulted in an increase in the $L I$ index. The total iron concentration of effluents in DWDS-GW was $1.78 \mathrm{mg} \mathrm{L}^{-1}$ at $7 \mathrm{~d}$, and increased to $2.32 \mathrm{mg} \mathrm{L}^{-1}$ at $11 \mathrm{~d}$. Then it showed a little fluctuation at around $2 \mathrm{mg} \mathrm{L}^{-1}$ from $11 \mathrm{~d}$ to $50 \mathrm{~d}$. After that, it gradually decreased to $1.62 \mathrm{mg} \mathrm{L}^{-1}$ at $73 \mathrm{~d}$, but quickly decreased to $0.33 \mathrm{mg} \mathrm{L}^{-1}$ at $91 \mathrm{~d}$, then fluctuated from 0.57 to $0.96 \mathrm{mg} \mathrm{L}^{-1}$ during 101 to $168 \mathrm{~d}$, and increased to approximately $1.09 \mathrm{mg} \mathrm{L}^{-1}$ after $168 \mathrm{~d}$ (Fig. 1). In DWDSs transporting SW, the concentration of total iron in effluents fluctuated from 1.05 to $1.92 \mathrm{mg} \mathrm{L}^{-1}$ before $70 \mathrm{~d}$, then decreased to 0.57 at $76 \mathrm{~d}$, but increased to approximately $1.83 \mathrm{mg} \mathrm{L}^{-1}$ after

Table 2

Water quality of water source and effluents.

\begin{tabular}{|c|c|c|c|c|}
\hline Parameters & GW & GW-effluent & SW & SW-effluent \\
\hline $\mathrm{pH}$ & $7.60-8.06^{\mathrm{a}}$ & $8.20 \pm 0.38^{b}$ & $7.62-8.10$ & $8.04 \pm 0.29$ \\
\hline $\mathrm{DO}\left(\mathrm{mg} \mathrm{L}^{-1}\right)$ & $7.35-7.46$ & $0.95 \pm 0.16$ & $7.93-8.27$ & $1.17 \pm 0.08$ \\
\hline $\mathrm{Cl}^{-}\left(\mathrm{mg} \mathrm{L}^{-1}\right)$ & $14.13-16.02$ & $31.45 \pm 2.80$ & $19.85-22.37$ & $43.06 \pm 3.30$ \\
\hline $\mathrm{SO}_{4}^{2-}\left(\mathrm{mg} \mathrm{L}^{-1}\right)$ & $21.41-24.85$ & $19.09 \pm 1.91$ & $50.22-76.46$ & $53.92 \pm 2.30$ \\
\hline $\mathrm{NO}_{3}^{-}-\mathrm{N}\left(\mathrm{mg} \mathrm{L}^{-1}\right)$ & $5.04-7.89$ & - & $0.87-2.17$ & - \\
\hline Alkalinity $\left(\mathrm{mg}^{\mathrm{c}} \mathrm{L}^{-1}\right)$ & $155-198$ & $118 \pm 7$ & $106-138$ & $88 \pm 5$ \\
\hline LI & $0.22-0.31$ & $0.61 \pm 0.15$ & $0.60-1.05$ & $1.41 \pm 0.17$ \\
\hline
\end{tabular}

a Value range.

b Mean \pm standard deviation.

c $\mathrm{mg} \mathrm{CaCO}_{3}$.

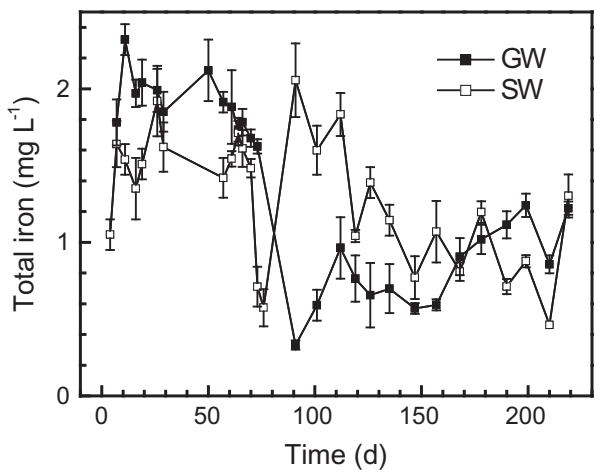

Fig. 1. Total iron concentration in effluents of GW and SW DWDSs with increasing time. 
Table 3

Corrosion rate (mm/year) in two waters for different time.

\begin{tabular}{lll}
\hline Time & GW & SW \\
\hline $31 \mathrm{~d}$ & $0.150 \pm 0.005$ & $0.156 \pm 0.000$ \\
$65 \mathrm{~d}$ & $0.0646 \pm 0.001$ & $0.142 \pm 0.005$ \\
\hline
\end{tabular}
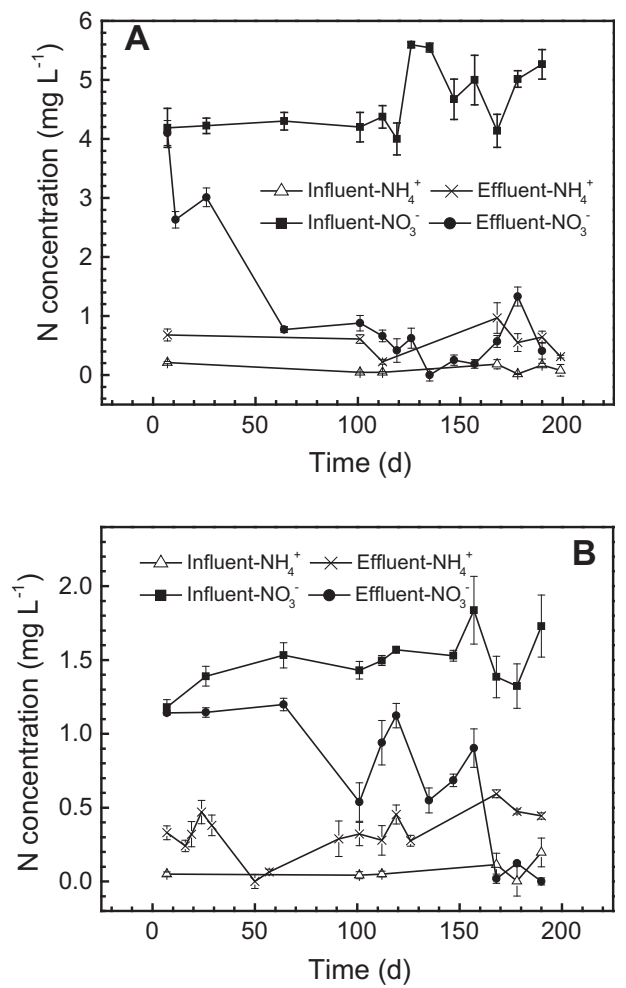

Fig. 2. Changes of nitrate and ammonium in influents and effluents in GW (A) and SW (B) DWDSs. Error bars represent one standard deviation.

$91 \mathrm{~d}$, and stabilized at approximately $1.03 \mathrm{mg} \mathrm{L}^{-1}$ except the point at $210 \mathrm{~d}$ (Fig. 1). Furthermore, the total iron concentration of effluents in the two DWDSs showed no significant difference $(p=0.68)$. However, for $31 \mathrm{~d}$ and $65 \mathrm{~d}$, the average weight loss values of the corrosion coupons were about 0.15 , and $0.0646 \mathrm{~mm} /$ year in $\mathrm{GW}$ DWDSs, while that ones were about 0.156 and $0.142 \mathrm{~mm} /$ year (Table 3) in SW DWDSs, indicating that iron release in two systems was not agreed with corrosion rate of iron.

In addition, the two DWDSs exhibit greatly changes of $\mathrm{NO}_{3}^{-}-\mathrm{N}$ with increasing time (Fig. 2). In GW DWDSs, $\mathrm{NO}_{3}^{-}-\mathrm{N}$ removal greatly increased about $3.53 \mathrm{mg} \mathrm{L}^{-1}$ before $64 \mathrm{~d}$, then gradually increased to $5.55 \mathrm{mg} \mathrm{L}^{-1}$ at $135 \mathrm{~d}$, and tended to a stable value of $4.28 \mathrm{mg} \mathrm{L}^{-1}$, while the concentration of $\mathrm{NH}_{4}^{+}-\mathrm{N}$ in effluent increased to a maximum about $0.78 \mathrm{mg} \mathrm{L}^{-1}$ throughout experimental time, indicating that most of nitrate were not transformed to ammonium. Also the nitrite concentration was below the detection limit during this period. The results suggested that most of nitrate was biologically denitrified to $\mathrm{N}_{2}$, not converted to ammonium by the reduction of zero-valent iron [36,37]. The same phenomena occurred in SW DWDSs, where $1 \mathrm{mg} \mathrm{L}^{-1}$ of $\mathrm{NO}_{3}^{-}-\mathrm{N}$ was removed after $130 \mathrm{~d}$.

\subsection{Characterization of corrosion scales on cast iron pipes}

Fig. 3 shows the XRD patterns of corrosion scales at different time points from DWDSs transporting GW and SW. In the GW DWDSs, the predominant crystalline corrosion product was goethite $(\alpha-\mathrm{FeOOH})$ with peak intensities increasing with increasing
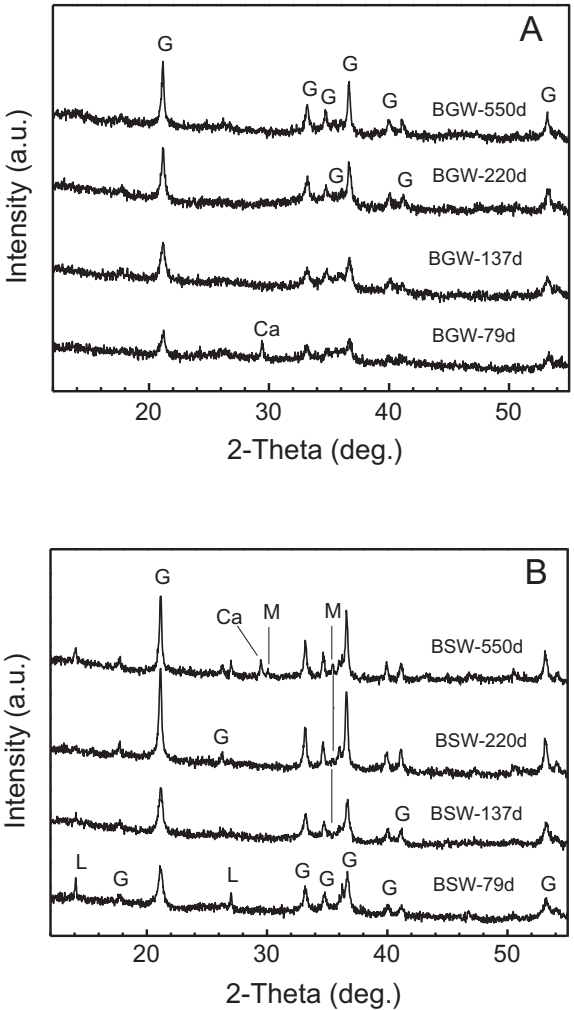

Fig. 3. XRD patterns of corrosion scales on cast iron pipes in DWDS-GW (A) and DWDS-SW (B) at different times $\left(\mathrm{Ca}-\mathrm{CaCO}_{3}, \mathrm{G}-\alpha-\mathrm{FeOOH}, \mathrm{L}-\gamma-\mathrm{FeOOH}, \mathrm{M}-\mathrm{Fe}_{3} \mathrm{O}_{4}\right)$.

exposure. In addition, $\mathrm{CaCO}_{3}$ was observed in the $79 \mathrm{~d}$ sample, and then disappeared in other samples. In the SW DWDSs, the main crystalline compounds were $\alpha-\mathrm{FeOOH}$ and $\gamma-\mathrm{FeOOH}$ in the sample after a $79 \mathrm{~d}$ exposure. The peak intensity of $\alpha$-FeOOH increased up to $220 \mathrm{~d}$ and then decreased from 220 to $550 \mathrm{~d}$, whereas the proportion of $\mathrm{Fe}_{3} \mathrm{O}_{4}$ increased with increasing time. The intensity of $\gamma$-FeOOH peaks decreased from 79 to $220 \mathrm{~d}$, and then increased with time, indicating that $\gamma$-FeOOH was unstable [9]. The results suggested that $\mathrm{Fe}_{3} \mathrm{O}_{4}$ was formed from the transformation of $\alpha-\mathrm{FeOOH}$ and $\gamma-\mathrm{FeOOH} . \mathrm{CaCO}_{3}$ appeared in samples from the $550 \mathrm{~d}$ exposure. Figs. 4 and 5 show representative SEM micrographs of the corrosion scales on the GW and SW DWDSs at different time points. The GW DWDSs exhibited loosely amorphous corrosion scales before $137 \mathrm{~d}$, and filaments of $\alpha$-FeOOH had formed by $220 \mathrm{~d}$. In the SW DWDSs, well-crystallized particles were observed at $79 \mathrm{~d}$, indicating the formation of a dense oxide layer, and more densely crystallized particles appeared at 137 and $220 \mathrm{~d}$, indicating stable protective layer formation. The BET surface areas of the corrosion scales were approximately 85.5 and $18.8 \mathrm{~m}^{2} \mathrm{~g}^{-1}$ from GW and SW DWDSs, respectively. This result confirmed that loose corrosion layers formed on the pipe transporting GW, while a compact corrosion layer formed on the pipe transporting SW, which agreed with the description from Yang et al. [8]. Furthermore, as a reference, in sanitized SW with chlorination, the corrosion scales were characterized by XRD and SEM in order to illustrate the impact of water chemical parameters and microorganisms on the structure of iron corrosion products. The main compounds were $\alpha-\mathrm{FeOOH}$ and $\mathrm{CaCO}_{3}$ (Fig. 6). These peak intensities increased with increasing time. There was no $\mathrm{Fe}_{3} \mathrm{O}_{4}$ formation in corrosion scales through the entire experimental period in sanitized water, and the corrosion products exhibited flowerlike crystals and porous structures (Fig. 7), and its BET surface area was approximately $50.8 \mathrm{~m}^{2} \mathrm{~g}^{-1}$. 

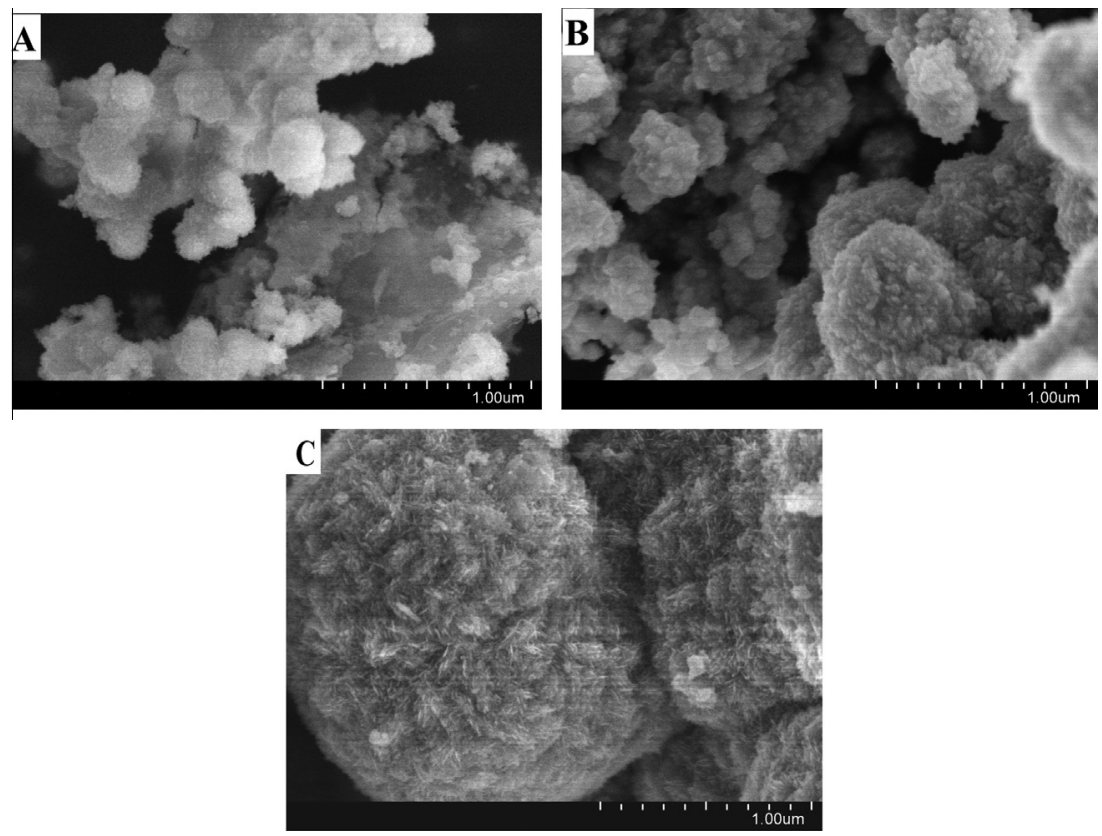

Fig. 4. SEM micrographs of corrosion scales in a GW pipe for different amounts of time (A: 79 d; B: 137 d; C: 220 d).
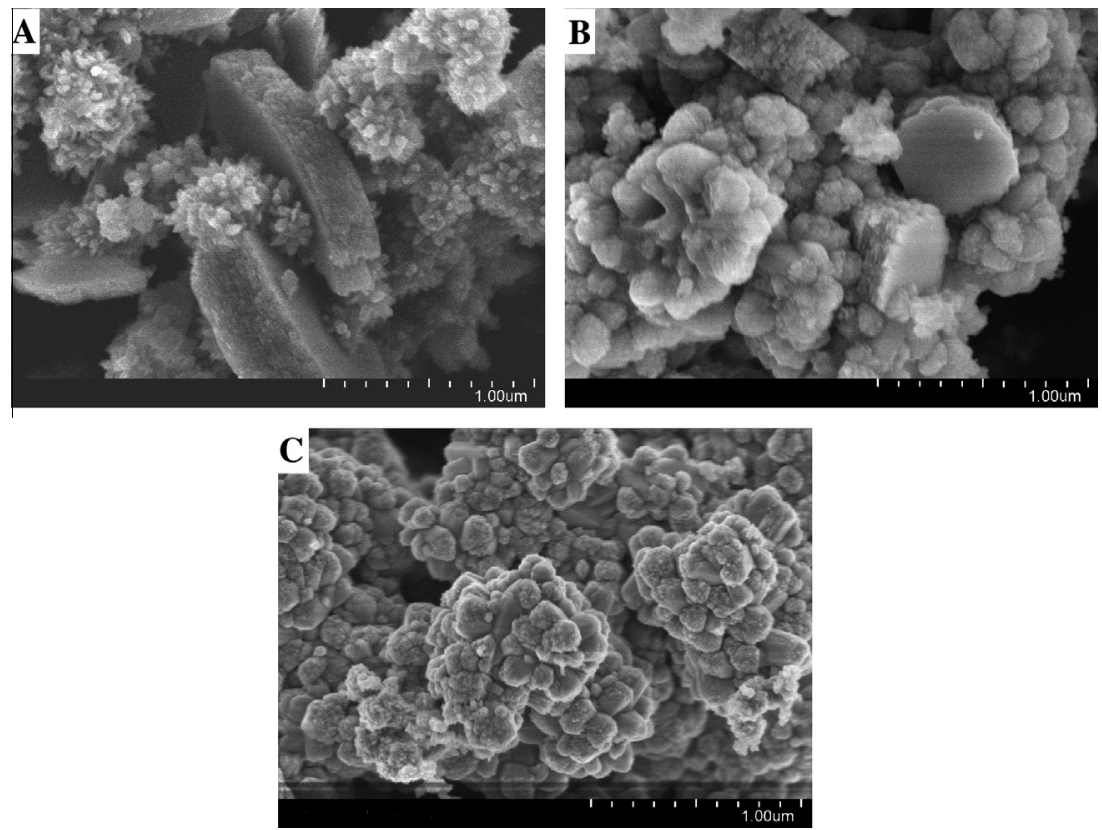

Fig. 5. SEM micrographs of corrosion scales in a SW pipe for different amounts of time (A: 79 d; B: 137 d; C: 220 d).

\subsection{Denitrifying functional genes and most probable number} enumerations

The $\mathrm{Fe}(\mathrm{II})$ oxidation and $\mathrm{Fe}(\mathrm{III})$ reduction were induced by respiration of some denitrifying bacteria [16], which may have affected the formation of corrosion products. Therefore, denitrifying functional genes were analyzed quantitatively by qPCR. Fig. 8 shows nosZ, nirS, nirK, and 16S rRNA gene copy numbers at different stages for the two DWDSs. In the source water and effluents from DWDSs, the $16 \mathrm{~S}$ rRNA gene copy number was $2.02 \times 10^{7}$ copies $\mathrm{mL}^{-1}$ in source GW, and it was not significantly different after $137 \mathrm{~d}$ $(p>0.05)$ and $220 \mathrm{~d}(p>0.05)$ in GW effluent (Fig. 8A), but it was approximately $1.23 \times 10^{11}$ copies $\mathrm{g}^{-1}$ in the biofilm (Fig. $8 \mathrm{C}$ ). For source SW, the $16 \mathrm{~S}$ rRNA gene copy number was $2.24 \times 10^{7}$ copies $\mathrm{mL}^{-1}$, and it was approximately $6.30 \times 10^{6}$ copies $\mathrm{mL}^{-1}$ in SW

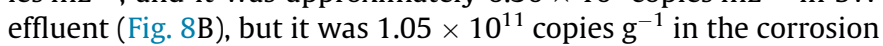
scale biofilm (Fig. 8C). The sum of nosZ, nirS and nirK increased from $1.48 \times 10^{5}$ copies $\mathrm{mL}^{-1}$ in source GW to $3.65 \times 10^{6}$ copies $\mathrm{mL}^{-1}$ in $\mathrm{GW}$ effluent, and it was $3.79 \times 10^{9}$ copies $\mathrm{g}^{-1}$ in the $\mathrm{GW}$ corrosion scale biofilm. The sum of nosZ, nirS and nirK increased from $1.42 \times 10^{5}$ copies $\mathrm{mL}^{-1}$ in source SW to $3.38 \times 10^{5}$ copies $\mathrm{mL}^{-1}$ in SW effluent, and it was $3.47 \times 10^{9}$ copies $\mathrm{g}^{-1}$ in the SW corrosion scale biofilm. Furthermore, in the biofilms within corrosion scales, MPN for NRB, IRB and nitrate-dependent Fe(II)-oxidizing bacteria were determined under different culture conditions. For GW and SW DWDSs, in the presence of $\mathrm{NO}_{3}^{-}$and acetate, culturable NRB were 
Fig. 6. XRD patterns of corrosion scales on cast iron coupons in sanitized SW water $\left(\mathrm{Ca}-\mathrm{CaCO}_{3}, \mathrm{G}-\alpha-\mathrm{FeOOH}\right)$.

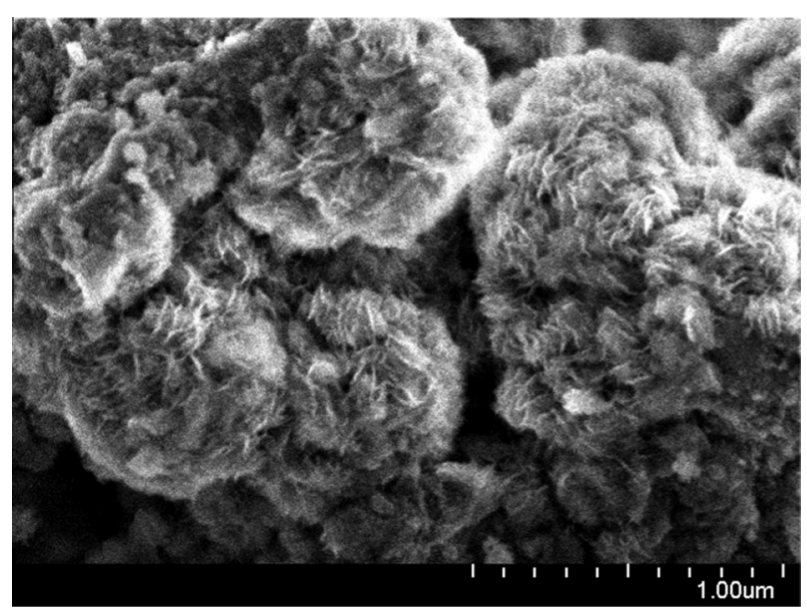

Fig. 7. SEM micrographs of corrosion scales formed on cast iron coupons in

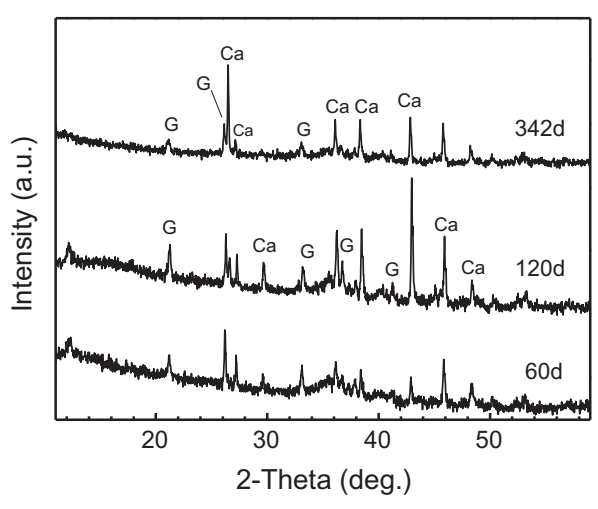
sanitized SW water.

detected approximately $2.7 \times 10^{7}$ and $7.5 \times 10^{6}$ cells $^{-1}$, and in the presence of $\mathrm{Fe}(\mathrm{III})$ and acetate, the abundances of culturable IRB were approximately $10^{3}$ and $10^{7}$ cells $\mathrm{g}^{-1}$, respectively, whereas approximately $10^{8}$ cells $\mathrm{g}^{-1}$ and $10^{6}$ cells $\mathrm{g}^{-1}$ of culturable (MPN assay) nitrate-dependent $\mathrm{Fe}(\mathrm{II})$-oxidizing microorganisms were detected with $\mathrm{Fe}(\mathrm{II})$ and $\mathrm{NO}_{3}^{-}$(Table 4). According to the previous work [16,38], biological nitrate-dependent $\mathrm{Fe}(\mathrm{II})$ oxidation came from IRB and NRB, and NRB also could reduce Fe(III) at the lower concentration of $\mathrm{NO}_{3}^{-}(<0.5 \mathrm{mM})$. These results indicated that NRB in DWDSs are able to induce oxidation of Fe(II) or reduction of $\mathrm{Fe}(\mathrm{III})$ in the presence or absence of nitrate. Moreover in GW DWDSs, nitrate-dependent $\mathrm{Fe}(\mathrm{II})$ oxidation was predominant within corrosion scales, but the reduction of Fe(III) by NRB and IRB were predominant inside corrosion scales in SW DWDSs.

\subsection{Bacterial diversity and composition in biofilms and water}

Pyrosequencing yielded a total of 51,421 high-quality 16S rRNA gene sequences for all samples. Table 5 shows the diversity indices of bacteria for different samples. The Shannon index was 4.79 and 5.83 for raw GW and SW, respectively, and became 2.62 and 4.19 for the effluents. The results indicated that raw SW had higher bacterial diversity than raw GW, and chlorine disinfection inhibited bacterial activity in the DWDSs. However, the biofilms in both systems had nearly the same Shannon index, indicating the same bacterial diversity within the biofilms.

Table 6 shows a taxonomic breakdown at the class level for GW and SW samples. In raw water, the major classes were Alphaproteobacteria (25.4\%), Gammaproteobacteria (23.2\%), and Sphingobacteria (20\%); Betaproteobacteria (6.6\%), and Actinobacteria (3.5\%) constituted the other minor classes. In effluent, Alphaproteobacteria became the most abundant class (86.7\%), Betaproteobacteria increased to $10.6 \%$, Sphingobacteria decreased to $2.4 \%$, and Gammaproteobacteria and other bacteria disappeared. For biofilm samples from the GW DWDSs at $137 \mathrm{~d}$, the dominant class was Betaproteobacteria (79.4\%), and the other minor classes were Alphaproteobacteria (13.1\%), Sphingobacteria (5.6\%), and Gammaproteobacteria (1.7\%); however at $220 \mathrm{~d}$, Betaproteobacteria decreased to $40.2 \%$,
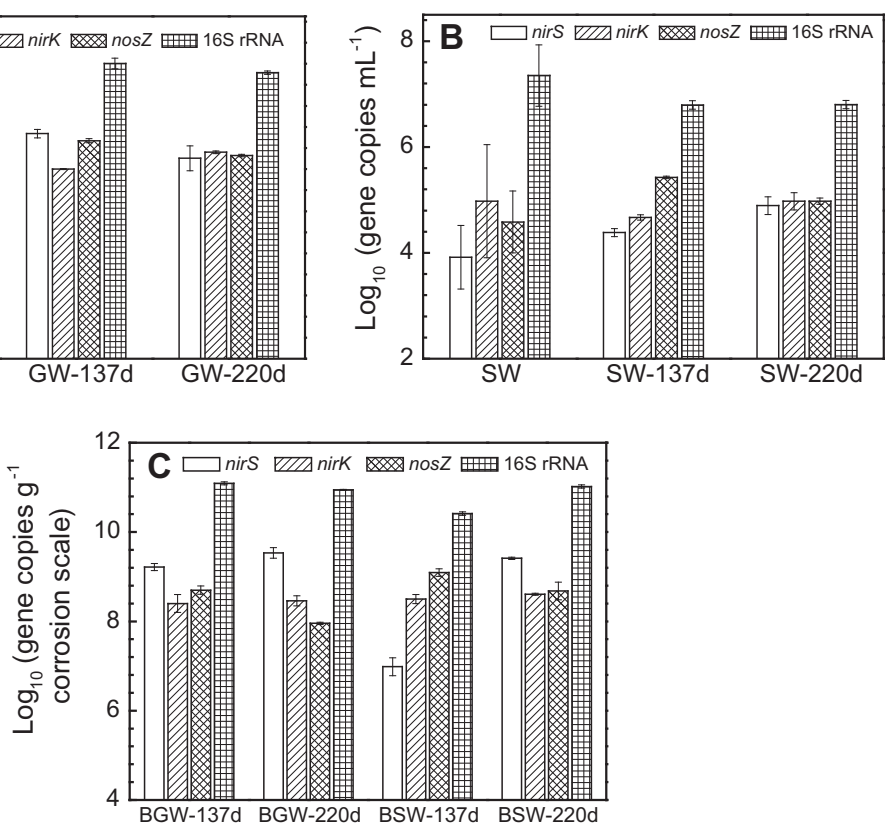

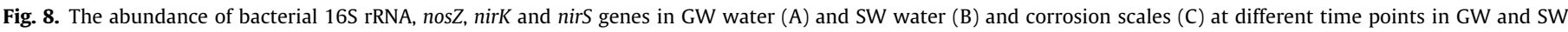
DWDSs. Error bars represent one standard deviation. 
Table 4

MPN enumerations of nitrate-reducing, Fe(III)-reducing and nitrate-dependent Fe(II)-oxidizing microorganisms in corrosion scales of DWDSs.

\begin{tabular}{|c|c|c|c|c|}
\hline \multirow[t]{2}{*}{ Culture conditions } & \multicolumn{2}{|c|}{ MPN (cells g $\left.{ }^{-1}\right)$} & \multicolumn{2}{|c|}{ 95\% confidence interval } \\
\hline & GW DWDS & SW DWDS & GW DWDS & SW DWDS \\
\hline Acetate $+\mathrm{NO}_{3}^{-}$ & $2.7 \times 10^{7}$ & $7.5 \times 10^{6}$ & $5.7 \times 10^{6}-1.2 \times 10^{8}$ & $1.9 \times 10^{6}-2.1 \times 10^{7}$ \\
\hline Acetate + Fe(III) & $5.8 \times 10^{3}$ & $4.6 \times 10^{7}$ & $1.1 \times 10^{3}-2.3 \times 10^{4}$ & $1.7 \times 10^{7}-1.9 \times 10^{8}$ \\
\hline $\mathrm{Fe}(\mathrm{II})+\mathrm{NO}_{3}^{-}$ & $1.6 \times 10^{8}$ & $1.3 \times 10^{6}$ & $2.8 \times 10^{7}-6.6 \times 10^{8}$ & $2.2 \times 10^{5}-5.2 \times 10^{6}$ \\
\hline
\end{tabular}

Table 5

Community diversity estimates of the bacteria within bulk water and corrosion scales at different time points in GW and SW DWDSs.

\begin{tabular}{lrll}
\hline Samples & OTUs & \multicolumn{2}{l}{ Diversity indices } \\
\cline { 3 - 4 } & & Shannon & Simpson \\
\hline GW & 784 & 4.79 & 0.0302 \\
GW-220 d & 443 & 2.62 & 0.03357 \\
BGW-137 d & 762 & 4.15 & 0.0534 \\
BGW-220 d & 620 & 4.14 & 0.0719 \\
SW & 1286 & 5.83 & 0.01 \\
SW-220 d & 567 & 4.19 & 0.0414 \\
BSW-137 d & 317 & 3.29 & 0.0944 \\
BSW-220 d & 581 & 4.13 & 0.0614 \\
\hline
\end{tabular}

GW (groundwater source); GW-220 d (groundwater effluent at $220 \mathrm{~d}$ ); BGW (corrosion scales of GW DWDSs); SW (surface water source); SW-220 d (surface water effluent at $220 \mathrm{~d}$ ); BSW (corrosion scales of SW DWDSs).

Alphaproteobacteria was $12.9 \%$, Sphingobacteria increased to $30.2 \%$, Holophagae (13.4\%) and Gemmatimonadetes (2.9\%) appeared, and Gammaproteobacteria disappeared. In raw SW, classes Alphaproteobacteria (35.8\%), Betaproteobacteria (27\%), and Gammaproteobacteria (12.5\%) were included. Sphingobacteria was $11.3 \%$, and Actinobacteria was $3.5 \%$. In effluent, the relative abundance of Alphaproteobacteria and Betaproteobacteria increased to $50.4 \%$ and $40.7 \%$, respectively, Sphingobacteria decreased to $8.1 \%$, and other bacteria were below $1 \%$. For biofilm samples from the SW DWDS at $137 \mathrm{~d}$, the groups were Alphaproteobacteria (23.1\%), Betaproteobacteria (68.8\%) and Sphingobacteriia (7.8\%); however at $220 \mathrm{~d}$, Alphaproteobacteria decreased slightly to $14.5 \%$, Betaproteobacteria increased to $78.3 \%$, and Sphingobacteria was $7 \%$. None of these classes changed greatly, indicating the stability of the biofilm in the DWDSs transporting SW.

Furthermore, the community structures of these dominant bacteria were compared at the genus level for different samples (Table 7). The compositions of corrosion-related bacteria underwent large changes in bulk water and biofilms on pipes transporting GW and SW. In raw GW, the dominant bacteria were IOB Sediminibacterium [39] (19.2\%), with other iron-respiring bacteria and NRB below $0.8 \%$. In effluent, the Sediminibacterium decreased to $2.4 \%$. NRB associated with redox cycling of iron (NRB-Fe) appeared at 5.8\%, including Zoogloea [36,40] (2.75\%), Aquabacterium [41]
(1.54\%), Azospira [42] (0.63\%), Dechloromonas [16] (0.42\%), and Hyphomicrobium [36,43] (0.29\%). In addition, the NRB producing siderophore (NRB-S) Sphingomonas [44] (2.6\%) appeared. In the biofilm of the GW DWDS at $137 \mathrm{~d}$, the IOB Sediminibacterium was 5.6\%, and NRB-Fe were $26.8 \%$, including Azospira (15.5\%), Dechloromonas (5.9\%), Acidovorax [45] (3.2\%), and Rhodanobacter [46] (1.6\%). Bradyrhizobium (8.4\%) and Sphingomonas (0.1\%) were NRB-S [47]. At 220 d, IOB Sediminibacterium increased to 30.1\%. The Geothrix [48] (12.4\%) IRB appeared, while NRB-Fe decreased to $20 \%$, including Azospira (9.6\%), Dechloromonas (6\%), and Zoogloea (3.6\%). Bradyrhizobium decreased to $4.99 \%$, and Sphingomonas was $0.1 \%$. In raw SW, the IOB Sediminibacteria was $9.5 \%$ and IRB Rhodobacter [49] was $1.2 \%$. NRB-S Sphingomonas was $8.4 \%$. In effluent, the IOB Sediminibacteria decreased to $7.5 \%$, and Rhodobacter decreased to $0.28 \%$. NRB-Fe increased to $28.4 \%$, including Zoogloea (13.1\%), Azospira (7.1\%), Dechloromonas (5.2\%), and Hyphomicrobium (2.8\%), but Sphingomonas increased to $16.9 \%$. In the biofilm of SW DWDSs at $137 \mathrm{~d}$, Sediminibacterium was $7.8 \%$, and no significant IRB were detected. However, the NRB-Fe comprised 58.7\%, mainly including Acidovorax (56.8\%) and Rhodopseudomonas [36] (1.5\%). Sphingomonas was 6\%. At $220 \mathrm{~d}$, NRB-Fe increased to 64.6\%, including Azospira (29.9\%), Dechloromonas (17.7\%), Zoogloea (8.8\%), Rhodopseudomonas (8.3\%) and Acidovorax (5\%). Sediminibacterium was 7\%. NRB-S Sphingomonas decreased to below $1 \%$.

\section{Discussion}

In DWDSs, iron pipe corrosion, chlorination and transformation of nitrate resulted in the large changes in the bacterial communities from water sources to effluents for GW and SW. However, both the effluents and the biofilms exhibited nearly the same bacterial community types in the two systems at $220 \mathrm{~d}$. The composition of the bacterial communities from both water sources had a large influence on the communities of the biofilms, leading to different bacterial community compositions in the two systems. Furthermore, all the biomass in the effluent of the GW DWDSs was greater than in the SW effluent, which was due to bacteria detaching from the loose corrosion layer in the GW DWDSs. However at $220 \mathrm{~d}$, there was almost same biomass inside the corrosion scales for the two systems. Significantly, denitrifying functional gene copy numbers increased with increasing corrosion time in the effluent

Table 6

Relative abundance of the major phylotypes at class level within bulk water and corrosion scales at different time points in GW and SW DWDSs.

\begin{tabular}{|c|c|c|c|c|c|c|c|c|}
\hline & GW & GW-220 d & BGW-137d & BGW-220 d & SW & SW-220 d & BSW-137 d & BSW-220 d \\
\hline Actinobacteria & 3.54 & 0.00 & 0.03 & 0.00 & 1.04 & 0.04 & 0.00 & 0.00 \\
\hline Alphaproteobacteria & 25.43 & 86.62 & 13.05 & 12.94 & 35.77 & 50.35 & 23.10 & 14.46 \\
\hline Betaproteobacteria & 6.60 & 10.62 & 79.38 & 40.20 & 27.03 & 40.7 & 68.82 & 78.32 \\
\hline Deltaproteobacteria & 0.38 & 0.05 & 0.00 & 0.16 & 2.77 & 0.04 & 0.00 & 0.00 \\
\hline Flavobacteria & 0.00 & 0.00 & 0.00 & 0.00 & 2.40 & 0.00 & 0.02 & 0.00 \\
\hline Gammaproteobacteria & 23.16 & 0.11 & 1.74 & 0.16 & 12.46 & 0.18 & 0.25 & 0.02 \\
\hline Gemmatimonadetes & 0.08 & 0.05 & 0.01 & 2.91 & 0.43 & 0.00 & 0.00 & 0.00 \\
\hline Holophagae & 0.00 & 0.11 & 0.16 & 13.38 & 0.00 & 0.02 & 0.00 & 0.11 \\
\hline Sphingobacteria & 20.00 & 2.39 & 5.62 & 30.19 & 11.34 & 8.06 & 7.82 & 7.03 \\
\hline Others (unknown etc.) & 20.81 & 6.76 & 0.05 & 0.61 & 0.01 & 0.06 & 0.00 & 0.06 \\
\hline
\end{tabular}

Only bacterial species representing $1 \%$ or more of total bacterial sequencing reads are shown. 
Table 7

Relative abundance of corrosion-related bacterial genera in bulk water and corrosion scales at different time points in GW and SW DWDSs.

\begin{tabular}{|c|c|c|c|c|c|c|c|c|}
\hline & GW & GW-220 d & BGW-137 d & BGW-220 d & SW & SW-220 d & BSW-137 d & BSW-220 d \\
\hline \multicolumn{9}{|l|}{ IOB } \\
\hline Sediminibacterium & 19.19 & 2.36 & 5.62 & 30.11 & 9.54 & 7.46 & 7.82 & 7.03 \\
\hline \multicolumn{9}{|l|}{ IRB } \\
\hline Goethrix & 0.00 & 0.00 & 0.00 & 12.39 & 0.00 & 0.00 & 0.00 & 0.00 \\
\hline Rhodobacter & 0.69 & 0.02 & 0.05 & 0.29 & 1.22 & 0.28 & 0.00 & 0.00 \\
\hline \multicolumn{9}{|l|}{ NRB-Fe } \\
\hline Acidovorax & 0.02 & 0.21 & 3.15 & 0.44 & 0.02 & 0.23 & 56.83 & 5.03 \\
\hline Azospira & 0.00 & 0.63 & 15.52 & 9.60 & 0.00 & 7.13 & 0.00 & 29.94 \\
\hline Aquabacterium & 0.00 & 1.54 & 0.01 & 0.02 & 0.70 & 0.00 & 0.00 & 0.00 \\
\hline Dechloromonas & 0.00 & 0.42 & 5.94 & 6.02 & 0.00 & 5.17 & 0.00 & 17.65 \\
\hline Zoogloea & 0.00 & 2.75 & 0.58 & 3.56 & 0.00 & 13.1 & 0.00 & 8.82 \\
\hline Rhodanobacter & 0.00 & 0.00 & 1.60 & 0.07 & 0.00 & 0.00 & 0.00 & 0.00 \\
\hline Rhodopseudomonas & 0.12 & 0.00 & 0.02 & 0.24 & 0.06 & 0.02 & 1.53 & 8.28 \\
\hline Hyphomicrobium & 0.04 & 0.29 & 0.00 & 0.05 & 0.23 & 2.78 & 0.04 & 0.11 \\
\hline \multicolumn{9}{|l|}{ NRB-S } \\
\hline Sphingomonas & 0.26 & 2.6 & 0.14 & 0.10 & 8.38 & 16.87 & 5.95 & 0.06 \\
\hline Bradyrhizobium & 0.16 & 0.00 & 8.38 & 4.99 & 0.06 & 0.00 & 0.08 & 1.16 \\
\hline
\end{tabular}

Only bacterial species representing $1 \%$ or more of total bacterial sequencing reads are shown.

and biofilm inside corrosion scales, and most of $\mathrm{NO}_{3}^{-}-\mathrm{N}$ was removed by denitrification in the two DWDSs. The concentration of $\mathrm{NO}_{3}^{-}-\mathrm{N}\left(5-7.9 \mathrm{mg} \mathrm{L}^{-1}\right)$ in $\mathrm{GW}$ were much higher than SW (0.9-2.2 $\left.\mathrm{mg} \mathrm{L}^{-1}\right)$, leading higher denitrification reaction, inducing higher nitrate-dependent Fe(II) oxidation than SW DW. The MPN enumerations also suggested that nitrate-dependent $\mathrm{Fe}(\mathrm{II})$ oxidation occurred predominantly by NRB-Fe and IOB in GW DWDS, whereas the reduction of $\mathrm{Fe}(\mathrm{III})$ and the oxidation of $\mathrm{Fe}(\mathrm{II})$ occurred via the anaerobic respiration of NRB-Fe in SW DWDSs. These different iron redox processes may affect the re-precipitation of released iron ions, the formation of corrosion products and the characteristics of microorganisms in the two DWDSs. The corrosion scales were thin and loosely bound reddish filaments of $\alpha$-FeOOH in the DWDS transporting GW while the dominant corrosion-related bacteria were IOB Sediminibacterium (30.1\%), IRB Geothrix (12.4\%), and NRB-Fe Azospira (9.6\%), Dechloromonas (6\%), and Zoogloea (3.6\%) within the biofilm. Conversely, the corrosion scales were thick, hard-shell tubercles consisting of $\mathrm{Fe}_{3} \mathrm{O}_{4}$ and $\alpha$-FeOOH, and the main corrosion-related bacteria were Azospira (29.9\%), Dechloromonas (17.7\%), Zoogloea (8.8\%) and Rhodopseudomonas (8.3\%) in the DWDSs transporting SW. In the sanitized SW (without biofilm), loose corrosion scales without $\mathrm{Fe}_{3} \mathrm{O}_{4}$ were formed, although the water had the same chemical parameters as the SW DWDSs. The results indicated that the biofilm may play a greater role than water chemical parameters in formation of $\mathrm{Fe}_{3} \mathrm{O}_{4}$ and the dense oxide layer. Previous works have verified that the reddish filament morphology of $\alpha$-FeOOH was mainly formed from the microbial oxidation of $\mathrm{Fe}(\mathrm{II})$ in a geological environment [50]. Moreover, some studies indicated that anaerobic iron redox cycling could be catalyzed by a single group of Azospira, Dechloromonas and IRB, and favor the formation of $\mathrm{Fe}_{3} \mathrm{O}_{4}[15,16]$, causing formation of more compact corrosion scales [8,51]. In addition, nitratedependent $\mathrm{Fe}(\mathrm{II})$ oxidation has been suggested to have a direct role in the formation of $\mathrm{Fe}_{3} \mathrm{O}_{4}$; however, its role was weaker than that of anaerobic iron redox cycling [15]. In the corrosion processes of iron pipes, iron ions were released into distributed water, and can re-precipitate forming corrosion scales [4]. The total iron concentration in bulk water depended on iron corrosion rate, re-precipitation rate and dissolution rate of corrosion scales [52]. In SW DWDSs, the re-precipitation rate of released iron ions was higher than that one in GW DWDSs due to anaerobic iron redox cycling, leading to similar total iron concentration in both DWDSs. Formation of $\mathrm{Fe}_{3} \mathrm{O}_{4}$ and a dense corrosion layer greatly depended on the composition of the bacterial community in the biofilm inside the corrosion layer and the concentration of nitrate microbial reduction in DWDSs.

\section{Conclusions}

The results showed that a loose corrosion layer was formed containing reddish filaments of $\alpha$-FeOOH with a BET surface area of $85.5 \mathrm{~m}^{2} \mathrm{~g}^{-1}$ in DWDS-GW, but in DWDS-SW, a dense corrosion layer was formed, including crystallized particles of $\alpha$-FeOOH, $\gamma$ $\mathrm{FeOOH}, \mathrm{Fe}_{3} \mathrm{O}_{4}$ and $\mathrm{CaCO}_{3}$ with a BET surface area of $18.8 \mathrm{~m}^{2} \mathrm{~g}^{-1}$. In sanitized $\mathrm{SW}, \alpha$-FeOOH and $\mathrm{CaCO}_{3}$ were formed with a loose and porous morphology with a BET surface area of $50.8 \mathrm{~m}^{2} \mathrm{~g}^{-1}$. These results indicated that microorganisms played a larger role in the formation of $\mathrm{Fe}_{3} \mathrm{O}_{4}$ and the properties of the corrosion layer than water chemical parameters. Both bulk bacteria in the effluent and biofilm inside the iron corrosion products had almost the same bacterial community composition for the two DWDSs with GW and SW. The total biomass, including total microorganisms and denitrifying functional bacteria, in the effluent of the GW DWDSs was much larger than in the SW DWDSs due to the loose corrosion layer in the GW DWDSs. However, bacterial diversity, denitrifying functional genes and 16S rRNA gene copy numbers of biofilms were nearly the same in the two systems after $220 \mathrm{~d}$, but the composition of the bacterial communities was very different due to the effect of the water source. With formation of the corrosion layer, the dominant corrosion-related bacteria were IOB Sediminibacterium (30.1\%), IRB Geothrix (12.4\%), and NRB associated with iron redox cycling (NRB-Fe) (20\%), including Azospira, Dechloromonas and Zoogloea within the biofilm in DWDS-GW at $220 \mathrm{~d}$, and NRBFe $(64.7 \%)$ were dominant, including the above NRB-Fe and Rhodopseudomonas, in DWDS-SW. Based on the MPN enumerations and qPCR of denitrifying functional bacteria, the formation of corrosion products was mainly affected by nitrate-dependent $\mathrm{Fe}(\mathrm{II})$ oxidation of NRB-Fe and Fe(II) oxidation of IOB Sediminibacterium in the DWDSs transporting GW, but reduction of Fe(III) and oxidation of $\mathrm{Fe}(\mathrm{II})$ occurred from the anaerobic respiration of NRB-Fe in the DWDSs transporting SW.

\section{Acknowledgments}

This work was supported by the National Natural Science Foundation of China (Nos. 21125731 and 51221892), the Federal Department of Chinese Water Control and Treatment (No. 
2012ZX07404002) and special fund of the State Key Laboratory of Environmental Aquatic Chemistry (No. 13L01ESPC).

\section{References}

[1] L.S. McNeill, M. Edwards, Iron pipe corrosion in distribution systems, J. Am. Water Works Assoc. 93 (2001) 88-100.

[2] S.A. Irman, J.D. Dietz, G. Mutoti, J.S. Taylor, A.A. Randall, C.D. Cooper, Red water release in drinking water distribution systems, J. Am. Water Works Assoc. 97 (2005) 93-100.

[3] P.S. Husband, J.B. Boxall, Asset deterioration and discolouration in water distribution systems, Water Res. 45 (2011) 113-124.

[4] T.L. Gerke, J.B. Maynard, M.R. Schock, D.L. Lytle, Physiochemical characterization of five iron tubercles from a single drinking water distribution system: possible new insights on their formation and growth Corros. Sci. 50 (2008) 2030-2039.

[5] S. Reiber, S. Poulsom, S.A.L. Perry, M. Edwards, S. Patel, D.M. Dodrill, A General Framework for Corrosion Control Based on Utility Experience, AWWA Research Foundation, Denver, CO, 1997.

[6] T. Brodeur, F.S. Davis, R. Florence, M. Kim, M. Craig, J. Gianatasio, D. Sharp, P. Lowe, From red water to pump failures-corrosion control activities \& related studies, Florida Water Resour. J. 12 (2006) 42-48.

[7] Z.J. Tang, S.K. Hong, W.Z. Xiao, J. Taylor, Characteristics of iron corrosion scales established under blending of ground, surface, and saline waters and their impacts on iron release in the pipe distribution system, Corros. Sci. 48 (2006) 322-342.

[8] F. Yang, B.Y. Shi, J.N. Gu, D.S. Wang, M. Yang, Morphological and physicochemical characteristics of iron corrosion scales formed under different water source histories in a drinking water distribution system, Water Res. 46 (2012) 5423-5433.

[9] A. Sander, B. Berghult, A.E. Broo, E.L. Johansson, T. Hedberg, Iron corrosion in drinking water distribution systems-the effect of $\mathrm{pH}$, calcium and hydrogen carbonate, Corros. Sci. 38 (1996) 443-455

[10] P.G. Medihala, J.R. Lawrence, G.D.W. Swerhone, D.R. Korber, Transient response of microbial communities in a water well field to application of an impressed current, Water Res. 47 (2013) 672-682.

[11] V. Rajeswari, D. Kesavan, M. Gopiraman, P. Viswanathamurthi, Physicochemical studies of glucose, gellan gum, and hydroxypropyl cellulose-Inhibition of cast iron corrosion, Carbohydr. Polym. 95 (2013) 288-294.

[12] G. Sahoo, R. Balasubramaniam, On the corrosion behaviour of phosphoric irons in simulated concrete pore solution, Corros. Sci. 50 (2008) 131-143.

[13] C.Y. Peng, J.F. Ferguson, G.V. Korshin, Effects of chloride, sulfate and natural organic matter (NOM) on the accumulation and release of trace-level inorganic contaminants from corroding iron, Water Res. 47 (2013) 5257-5269.

[14] L.K. Herrera, H.A. Videla, Role of iron-reducing bacteria in corrosion and protection of carbon steel, Int. Biodeterior. Biodegrad. 63 (2009) 891-905.

[15] K.A. Weber, L.A. Achenbach, J.D. Coates, Microorganisms pumping iron: anaerobic microbial iron oxidation and reduction, Nat. Rev. Microbiol. 4 (2006) 752-764.

[16] K.A. Weber, M.M. Urrutia, P.F. Churchill, R.K. Kukkadapu, E.E. Roden, Anaerobic redox cycling of iron by freshwater sediment microorganisms, Environ. Microbiol. 8 (2006) 100-113.

[17] M.A. Javed, P.R. Stoddart, E.A. Palombo, S.L. McArthur, S.A. Wade, Inhibition or acceleration: bacterial test media can determine the course of microbiologically influenced corrosion, Corros. Sci. 86 (2014) 149-158.

[18] C. Pillay, J. Lin, The impact of additional nitrates in mild steel corrosion in a seawater/sediment system, Corros. Sci. 80 (2014) 416-426.

[19] A. Ashassi-Sorkhabi, M. Moradi-Haghighi, G. Zarrini, R. Javaherdashti, Corrosion behavior of carbon steel in the presence of two novel ironoxidizing bacteria isolated from sewage treatment plants, Biodegradation 23 (2012) 69-79.

[20] S.J. Yuan, B. Liang, Y. Zhao, S.O. Pehkonen, Surface chemistry and corrosion behaviour of 304 stainless steel in simulated seawater containing inorganic sulphide and sulphate-reducing bacteria, Corros. Sci. 74 (2013) 353-366.

[21] E. Valencia-Cantero, J.J. Pena-Cabriales, E. Martinez-Romero, The corrosion effects of sulfate- and ferric-reducing bacterial consortia on steel, Geomicrobiol. J. 20 (2003) 157-169.

[22] M. Dubiel, C.H. Hsh, C.C. Chien, F. Mansfeld, D.K. Newman, Microbial iron respiration can protect steel from corrosion, Appl. Environ. Microbiol. 68 (2002) 1440-1445.

[23] D. Xu, Y. Li, F. Song, T. Gu, Laboratory investigation of microbiologically influenced corrosion of C1018 carbon steel by nitrate reducing bacterium Bacillus licheniformis, Corros. Sci. 77 (2013) 385-390.

[24] Y. Zhu, H.B. Wang, X.X. Li, C. Hu, M. Yang, J.H. Qu, Characterization of biofilm and corrosion of cast iron pipes in drinking water distribution system with UV/ $\mathrm{Cl}_{2}$ disinfection, Water Res. 60 (2014) 174-181.

[25] R. Zuo, Biofilms: strategies for metal corrosion inhibition employing microorganisms, Appl. Microbiol. Biotechnol. 76 (2007) 1245-1253.
[26] EPA of China, Analysis Method for Water and Waste Water, fourth ed., Press of Chinese Environmental Science, Beijing, 2002.

[27] S.K.L. Ishii, T.H. Boyer, Evaluating the secondary effects of magnetic ion exchange: focus on corrosion potential in the distribution system, Desalination 274 (2011) 31-38.

[28] D. Li, Z. Li, J.W. Yu, N. Cao, R.Y. Liu, M. Yang, Characterization of bacterial community structure in a drinking water distribution system during an occurrence of red water, Appl. Environ. Microbiol. 76 (2010) 7171-7180.

[29] V. Gomez-Alvarez, R.P. Revetta, J.W. Santo Domingo, Metagenome analyses of corroded concrete wastewater pipe biofilms reveal a complex microbial system, BMC Microbiol. 12 (2012) 122.

[30] X. Zheng, Y.L. Su, X. Li, N.D. Xiao, D.B. Wang, Y.G. Chen, Pyrosequencing reveals the key microorganisms involved in sludge alkaline fermentation for efficient short-chain fatty acids production, Environ. Sci. Technol. 47 (2013) 42624268.

[31] M.T. Suzuki, L.T. Taylor, E.F. DeLong, Quantitative analysis of small-subunit rRNA genes in mixed microbial populations via 5'-nuclease assays, Appl. Environ. Microbiol. 66 (2000) 4605-4614.

[32] S. Henry, E. Baudouin, J.C. Lopez-Gutierrez, F. Martin-Laurent, A. Brauman, L. Philippot, Quantification of denitrifying bacteria in soils by nirK gene targeted real-time PCR, J. Microbiol. Methods 59 (2004) 327-335.

[33] E. Kandeler, K. Deiglmayr, D. Tscherko, D. Bru, L. Philippot, Abundance of narG, nirS, nirK, and nosZ genes of denitrifying bacteria during primary successions of a glacier foreland, Appl. Environ. Microbiol. 72 (2006) 5957-5962.

[34] I.N. Throback, K. Enwall, A. Jarvis, S. Halli, Reassessing PCR primers targeting nirS, nirK and nosZ genes for community surveys of denitrifying bacteria with DGGE, FEMS Microbiol. Ecol. 49 (2004) 401-417.

[35] M.L. Mccormick, P. Adriaens, Carbon tetrachloride transformation on the surface of nanoscale biogenic magnetite particles, Environ. Sci. Technol. 38 (2004) 1045-1053.

[36] J.P. Shapleigh, Denitrifying prokaryotes, in: E. Rosenberg, E.F. DeLong, S. Lory, E. Stackebrandt, F. Thonmpson (Eds.), The Prokaryotes, fourth ed., SpringerVerlag Press, Berlin, Heidelberg, 2006, pp. 405-421.

[37] P. Westerhoff, J. James, Nitrate removal in zero-valent iron packed columns, Water Res. 37 (2003) 1818-1830.

[38] K.T. Finneran, M.E. Housewright, D.R. Lovley, Multiple influences of nitrate on uranium solubility during bioremediation of uranium-contaminated subsurface sediments, Environ. Microbiol. 4 (2002) 510-516.

[39] H.B. Wang, C. Hu, X.X. Hu, M. Yang, J.H. Qu, Effects of disinfectant and biofilm on the corrosion of cast iron pipes in a reclaimed water distribution system, Water Res. 46 (2012) 1070-1078.

[40] Y. Sag, T. Kutsal, Biosorption of heavy metals by Zoogloea ramigera: use of adsorption isotherms and a comparison of biosorption characteristics, Chem. Eng. J. 60 (1995) 181-188.

[41] K.L. Straub, W.A. Schonhuber, B.E.E. Buchholz-Cleven, B. Schink, Diversity of ferrous iron-oxidizing, nitrate-reducing bacteria and their involvement in oxygen-independent iron cycling, Geomicrobiol. J. 21 (2004) 371-378.

[42] K.G. Byrne-Bailey, J.D. Coates, Complete genome sequence of the anaerobic perchlorate-reducing bacterium Azospira suillum strain PS, J. Bacteriol. 194 (2012) 2767-2768

[43] L.Y. Stein, M.T. La Duc, T.J. Grundl, K.H. Nealson, Bacterial and archaeal populations associated with freshwater ferromanganous micronodules and sediments, Environ. Microbiol. 3 (2001) 10-18.

[44] O.W. Duckworth, S.J.M. Holmstrom, J. Pena, G. Sposito, Biogeochemistry of iron oxidation in a circumneutral freshwater habitat, Chem. Geol. 260 (2009) 149158.

[45] C. Pantke, M. Obst, K. Benzerara, G. Morin, G.O. Nguema, U. Dippon, A. Kappler, Green rust formation during $\mathrm{Fe}(\mathrm{II})$ oxidation by the nitrate-reducing Acidovorax sp. strain BoFeN1, Environ. Sci. Technol. 46 (2011) 1439-1446.

[46] M. Blöthe, E.E. Roden, Composition and activity of an autotrophic Fe(II)oxidizing, nitrate-reducing enrichment culture, Appl. Environ. Microbiol. 75 (2009) 6937-6940.

[47] K. Arif, G. Archana, D.J. Anjana, Engineering heterologous iron siderophore complex utilization in rhizobia: effect on growth of peanut and pigeon pea plants, Appl. Soil Ecol. 53 (2012) 65-73.

[48] K.P. Nevin, D.R. Lovley, Mechanisms for accessing insoluble Fe(III) oxide during dissimilatory Fe(III) reduction by Geothrix fermentans, Appl. Environ. Microbiol. 68 (2002) 2294-2299.

[49] D. Lovley, Dissimilatory Fe(III)- and Mn(IV)-reducing prokaryotes, in: E. Rosenberg, E.F. DeLong, S. Lory, E. Stackebrandt, F. Thonmpson (Eds.), The Prokaryotes, fourth ed., Springer-Verlag Press, Berlin, Heidelberg, 2013, pp. 287-305.

[50] P.P. Provencio, V.J. Polyak, Iron oxide-rich filaments: possible fossil bacteria in Lechuguilla Cave, New Mexico, Geomicrobiol. J. 18 (2001) 297-309.

[51] D.A. Lytle, T.L. Gerke, J.B. Maynard, Effect of bacterial sulfate reduction on ironcorrosion scales, J. Am. Water Works Assoc. 97 (2005) 109-120.

[52] G. Mutoti, J.D. Dietz, S.A. Imran, J. Taylor, C.D. Cooper, Development of a novel iron release flux model for distribution systems, J. Am. Water Works Assoc. 99 (2007) 102-111. 